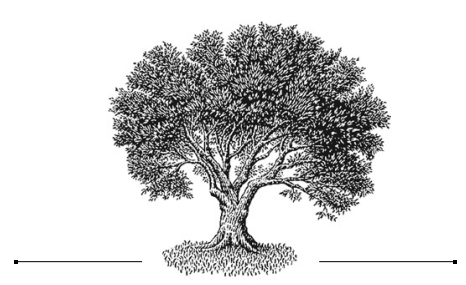

Slavic Relative čto/co:

between

Pronouns and Conjunctions
Славянское релятивное što/co между местоимениями и союзами

\section{Philip Minlos}

Institute for Slavic Studies of the Russian Academy of Sciences, Moscow

\section{Фидипп Робертович Миндос}

Институт славяноведения РАН, Москва

\title{
Abstract
}

This paper presents the key points concerning Slavic relative constructions with a group of kindred invariable lexemes: Russian umo, BCS što, Czech, Polish co, Slovak $\check{c}$, and their cognates. These constructions are classified into two main types, depending on whether the third-person pronoun is used for marking the relative target. Across Slavic languages, the parameters governing the distribution between the two types are closely connected. The interpretation of these parameters (as well as their microvariation) is presented within the functional-typological approach. Syntactic category (part of speech) of the lexemes is discussed in diachronic perspective: in the more innovative construction with third-person pronoun, čto functions more as a complementizer; in the more conservative construction without the pronoun, $\check{c} t o$ retains some pronoun traits.

\footnotetext{
Keywords

relative clause, syntax, grammaticalization
} 
0 . Introduction. This paper examines Slavic relative constructions with invariable lexemes stemming from Common Slavic *čsto (Russian umo, BCS - Bosnian / Croatian / Serbian što) or *čbso (Czech, Polish co, Slovak čo). In the following pages, čto stands for the full variety of Slavic forms.

The main diachronic source of čto in Slavic relative constructions was, undoubtedly, an inflected pronoun (the inflected lexeme exhibited a regular polysemy, functioning as either an interrogative, an indefinite, or a relative pronoun). As a result of a process of grammaticalization, the case forms of this pronoun formed various conjunctions (for instance, Croatian čim 'when' [MARETIĆ 1888: 73]). The invariable čto in relative constructions may also be viewed as a conjunction; at the same time, it shows traces of pronoun character. There are two main types of relative clauses introduced by the invariable čto. In one of the types, the relativized slot is explicitly marked by the third-person pronoun; in the other type, the additional pronoun is absent, but the form čto (which stems from the Nom.-Acc. form of the inflected pronoun) seems to represent the relative target. These two types are simultaneously present in most of the modern Slavic languages - BCS, Czech, Polish, Slovak, and Ukranian (the first one, with the third-person pronoun, is not found in Russian and Belorussian and presumably is more innovative). The most intriguing and revealing problem is the grammatical distribution of the two types. In this article, both Slavic morphosyntax and typological observations (accessibility hierarchy, markedness of animated direct object) are taken into account to explain the distribution of the two constructions.

Almost no new data is presented here. My goal, instead, is to combine heterogeneous accounts concerning the related constructions in Slavic languages and to place them in a broader context of the modern functional-typological approach. The relevant data is drawn both from the modern Slavic languages (in their standard and non-standard varieties) and from earlier sources (mostly mediaeval).

The paper is organized as follows. Section 1 provides some background typological information on relative pronouns in general and on Slavic relative pronouns that go back to interrogatives. Section 2 introduces the two main types of Slavic relative clauses with invariable čto (with and without third-person pronoun). Section 3 is a detour, discussing the placement of the third-person pronoun in these clauses. Section 4 focuses on the conditions of use for the two constructions under investigation, presenting both grammatical facts and theoretical reflections on the cut-off point between them. Section 5 discusses whether the lexeme čto may be called a pronoun or a conjunction. The diachronic development from an inflected lexeme to an invariable one is the subject of Section 6, and Section 7 offers some concluding remarks. 
1. Background facts. Cross-linguistically, the most widespread option for explicitly marking the function of the relativized NP in the relative clause is the use of third-person pronouns [KEENAN 1985: 146]. Another option is the use of relative pronouns, the latter being defined as pronouns "distinct from ordinary definite personal pronouns" [KeENAN 1985: 149]. Actually, the relative pronouns are more complex, as they mark both the $\mathrm{NP}_{\text {rel }}$ position and (with minor exceptions) the leftmost boundary of the relative clause [Givón 2001: 187; KEENAN 1985: 151]. Although relative pronouns are quite common in Indo-European languages, they are somewhat exotic among the world's languages as a whole (thus, they form part of the definition of Standard Average European in [HASPELMATH 2001]). Relative pronouns often coincide with (or are formally related to) interrogative pronouns [KEENAN 1985: 149-151; HEine, Kuteva 2004: 251; Heine, Kuteva 2006: 204-243; Harris, CAMPBelL 1995: 298]; see also the special survey of contact-induced replications of this model in [HeIne, Kuteva 2005: 3, 94 passim].

As a paradigm example of a relative pronoun case-marked for the $\mathrm{NP}_{\text {rel }}$ position, Russian которыü is often cited [ANDREWs 2007: 218; CRISTOFARO, RAMAT 2007: 65]. Somewhat ironically, it is precisely this pronoun that is scarcely ever used as an interrogative. The head of the corresponding relative clause is generally an NP constructed with a noun.

Slavic declinable čto participates in the regular polysemy model, being an interrogative, indefinite, and relative pronoun (on declinable relative čto, see Section 6). The Slavic kto-pronoun (Russian $\kappa m o$ and its cognates) exhibits a similar polyfunctionality. The interrogative $k t o$ comprises a pair with interrogative čto, as čto stands for inanimates ('what?') and kto for animates ('who?'). The relative pronoun $k t o$ is found in Polish and East Slavic languages. The use of $k$ to and čto as inflected relative pronouns is mostly limited to "light-headed" and "headless" relatives (those without a noun and those without any overt head, [Сітко 2004]), and their distribution follows that of interrogatives (čto for inanimates and kto for animates). But the use of invariable čto with full nouns is generally not restricted to inanimates.

2. Slavic relative constructions with invariable čto: two strategies. Slavic relative clauses with full-fledged nouns as heads, introduced by čto, fall into two major types depending on the explicit marking of $\mathrm{NP}_{\text {rel }}$ by a third-person pronoun:

- " $\quad$ bare čto" strategy: no additional means of marking the relative target position are employed. The relative target in (1) is in accusative case:

(1) peňiaze, čo nazbierali

money co collected

'money [they] have collected'

Slovak dialect in Hungary [ONDRUS 1956: 216] 
- “čto + pronoun" strategy: the inflected anaphoric pronoun in the appropriate case form (with the appropriate preposition) is used. The construction is known in many languages, including BCS, Slovenian, Ukrainian, Polish, Slovak, and Czech; it is not found in Russian and Belorussian. The pronoun may also be called resumptive. The pronoun forms in examples (1-3) are $f \check{n} о \mathrm{~m}$, o nim, на него:

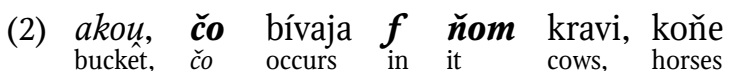
'bucket, in which sometimes.are cows, horses' Slovak dialect in Hungary [ONDRUs 1956: 236]

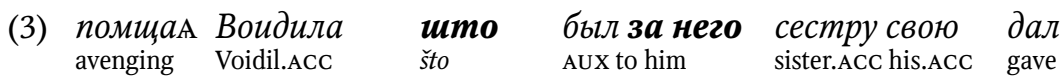
'avenging Voidil, to whom he gave his sister'

Ruthenian, Vilno chronicle, fifteenth-sixteenth century, the example is pointed out in [КАРСКИй 1955: 472]

(4) Poznatem wczoraj tego dzennikarza, co o nim byto tak głośno I.became.acquainted yesterday that journalist co about him was such noisy 'I became acquainted yesterday with the journalist they were making a lot of noise about' Polish [GROCHOWSKI ET AL. 1984: 345]

3. The placement of the anaphoric pronoun. These pronouns may be posited either in their neutral position after the verb, as in (3), or they may be moved to the clause edge, usually following older clitics, as in (3-4). John Haiman [HAIMAN 1985: 240] argues for a crucial difference between two types of pronouns standing for a relative target: relative pronouns are invariably placed close to the head, whereas clauses with anaphoric pronouns maintain unmarked word order (Haiman states that he has encountered only one language, Ute from the Uto-Aztecan family, "where the [anaphoric] pronoun is moved toward the head"). As the word order of most clausal constituents in Slavic languages is not strictly determined by grammatical relations, no single example like (2-3) can give evidence of the pronoun "moving" clause-initially. But at least some Slavic languages seem to favour the inital placement of the pronoun. For example, the speakers of modern Ukrainian I have consulted find example (5) rather unusual (they would prefer to say колесо, що на його зверху пада вода).

(5) се колесо, щзо зверху пада на його вода

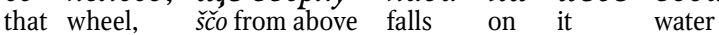

'that is the wheel, on which the water falls from above'

Ukrainian [ГРИнченко 4: 528]

Bernard Comrie [Comrie 1989: 150] points, as a possible theoretical option, to an analysis of Modern Czech co ho in a construction similar to (4) as a relative pronoun ("the pronoun gravitates towards sentence-initial position, 
giving rise to a single phonological word co-ho, marked as accusative case"). [KEENAN, COMRIE 1979b: 658] and [COMRIE 1989: 150] justifiably stress that the pronoun $h o$ is a clitic regardless of clause type. Nevertheless, phrases like (4) may indeed form new relative pronouns, if any extra material, even old clitics, does not intervene and phrases such as co o nim are grammaticalized into a single unit. This does not seem to be true for modern Slavic languages, though. Prepositions do not prevent a construction from becoming a single unit; compare Russian indefinite pronouns such as Nom. кoe-umo 'something' and the prepositional phrase кое о чем 'about something'. Still, the phrases that lack prepositions, such as (6), may grammaticalize more easily (another complex relativizer is exemplified in Macedonian кojumo, [LuNT 1952: 45]). It is appropriate to mention that the čto + pronoun construction is not frequent with prepositional phrases, as stated explicitly for BCS in [KuRzová 1981: 161-163].

(6) а жена несет ему младенца, что него родила Conj wife carries him baby čto him gave.birth 'in the meanwhile his wife the baby to whom she gave birth for him' Russian (southern dialects, R'azan' province), [АФАНАСьЕВ II, №220], quoted in [Борковский 1981: 206];

4. The distribution of the two constructions

4.1. The facts. Here we define the exact cut-off point between the "bare čto" contexts and the contexts in which the "bare čto" strategy is of very limited use. The clearest contexts for "bare čto" are clauses with a relativized subject. Still, some varieties of West Slavic languages allow the expansion of the thirdperson pronoun strategy into nominative case, as, for example, "sub-standard" Polish [GROCHOWSKI ET AL. 1984: 345] and Moravian dialects [BARTOŠ 1905: 37], but these cases are in the minority.

With the relativization of the direct object, much more variation is observed. In this context, some languages draw a distinction along the animacy line: with inanimate objects, the "bare čto" construction is employed (that is, inanimate objects are relativized the same as subjects); with animate objects, only the "čto + pronoun" strategy is used, if available. For Russian (where the second strategy is not available), the cut-off point is explicitly stated in [ГРЯ 1954, II/2: 275], although in the subsequent, more widely-known version (1980, reprinted in 2005) this detail was omitted; it is carefully pointed out in the subsequent literature, as in [KřIžKOVÁ 1970: 24], [GoLĄB, FRIEDMAN 1972], and [KuRzovÁ 1981: 80]. ${ }^{1}$ As resumptive pronouns are not an option in

1 The paper [ЗАлизняк, ПАдучевА 1978] provides exactly three other possible examples with čto: (1) with animate subject; (2) with inanimate subject; and (3) with inanimate object), thus implicitly pointing to the lack of examples with animate object. Likewise, [PUGH 2006] provides seventy-two examples of umo with full nouns in contemporary Russian prose. He notes "the significant number of animate nouns as antecedents, whereas the rules strongly indicate that these should normally be 
Russian, the distinction is between use and nonuse of čto-relatives. In other languages, the relativization of an animate object is mostly accompanied by the use of the third-person pronoun, as it is in Croatian [KoRDIĆ 1995: 160161] and in South Czech/Moravian dialects [Котт I: 139], [ВАRтоš 1905: 37]. ${ }^{2}$ The relevant examples are (7-8); in Serbian щоно (8), the relative що is suffixed by the particle $н$ :

(7) того человека,
that.Aсс
man.Aсс

и тую нашю челядь, что ваши торговции без кунъ их поимали and that. ACC our. ACC servants. ACC što your tradesmen without money them seized

'the man whom you have executed and our servants that your

tradesmen seized without money'

Ruthenian, letter of the Polotsk vice regent Ivan Sem'enovič to

Riga, 1409, quoted in [Борковский 1958: 123]

(8) за Фнеи момке щзно их Ю бостанжи баша 8 драч8

for those fellows štono them Aux Bostanži pasha in Drach.LOc arrested

'for those fellows whom pasha Bostanži has arrested'

Old Serbian, 1506/1507 [GALLIs 1956: 57]

The most widespread deviation from the animacy cut-off point lies in the expansion of the "čto + pronoun" construction to an inanimate direct object, as in examples (9-10):

(9) Chudobná děvečka nic jiného nema, jenom tu postivost', co si ju poor girl nothing other has only that chastity, co REfl it.ACC

zachová.

keeps

'A poor girl has nothing but the chastity she keeps'

Moravian [BARTOŠ 1905: 37]

(10) (...)posebnim pismom క̌to su ga zvali sad popovicom, sad Special.Inst writing.system.INSTR što AUX it.ACC was.called either "popovica" or glagoljicom.

"glagolica"

'with the special writing system that was called either popovica or

glagolica'

Croatian [НАмм 1974: 11]

The pattern is well attested in BCS [KoRDIĆ 1995: 160], and in Czech [FRIED 2010].

inanimate" [Pugh 2006: 221]. It is not clear which sources provide such rules. We have classified the material provided in [Pugh 2006: 221-223] depending on the case of the relativized target and the animacy of the noun: Nom., animate: 30; Nom., inanimate: 30; Acc., animate: 0 ; Acc., inanimate: 12 . The absence of animate targets in accusative is rather noticeable.

2 In [VONDRÁK 1908: 447] the examples are reproduced with reference to [Kott I: 139], the attribution "v již. Čechach" is replaced - as it seems, not correctly - to "Slovak". 
The other type of deviation is the use of the "bare čto" pattern with animate direct objects. It is not so easy to use native speakers' judgements, as čto is far from being the main strategy of relativization in Slavic languages. Using the web as a corpus for Russian (via Yandex search engine, www.yandex. $\mathrm{ru}$ ) proves difficult to find examples of čto with a relativizing animate direct object. Here are two of the obtained examples with девушка 'girl' (both examples seem to be not quite standard):

(11)
tell

'tell the girl whom I used to call Dus'a'

Russian, from the memoirs of F. Ranjevskaja

(12) Опятьже, девушка что вы описываете на Еську не «тянет»

But.again girl čto you describe like Jes'ka NEG look

'But again, the girl whom you describe does not look like Es'ka'

This kind of example is also rarely attested in Old Russian. Thus, no such example is found in [Борковский 1958: 121-122]). The following example is of this rare variety:

(13) $m \mathbf{t}$ люди што есм⿰ еи подавал при своемг живот'

Those people čto AUX.1sG her gave during REFL.Poss life

'those people that I gave her while alive'

Old Russian, testament of grand duke Vasilij Dmitrievič, dated 1406 [ЧЕРЕПНИН 1950, №20]).

Analysing properties of Russian čto-clauses, [ЗАлИЗНяк, ПАДУчЕвА 1975/2002] point to phrase (14), in which umo stands for the prepositional phrase (= в которую я влюблен).

(14) девушка, что я влюблен

girl cto I am.in.love

the girl with whom I am in love'

The exact phrase is a part of a popular song from a movie (shot in the 1940s), and is acceptable to Russian speakers only as a citation, an example of deviant language. The pattern is in very restricted use in colloquial Russian. Examples (15-16) are found on web blogs via Google (the original punctuation is preserved):

(15) Мой первый поцелуй с парнем, что я встречалась был в лоб:))) my first kiss with guy čto I went.out was on forehead

'My first kiss with the guy with whom I went out was on the forehead'

(16) Остальные люди что я тебе говорил, обещаются прийти позжее. other people čto I you.Dat told promise come.INF later 'The other people I told you about promise to come later' 
In this pattern, the target prepositional phrase should be easily recoverable: it might be either the main argument of the verb (15-16) or a locative or temporal adjunct - the locative adjunct is exemplified in (17-18).

The čto construction with locative meaning as in examples (17-18) was quite common in Middle Russian documents.

$\begin{array}{lllll}\begin{array}{l}\text { (17) деревня } \\ \text { village }\end{array} & \text { Голцово, пуста, что жил } \\ \text { Golcovo } & \text { deserted čto lived Mamюшка } & \text { Олексеев } \\ \text { Olekseev }\end{array}$

'village Golcovo, deserted, where Matjuška Olekseev lived'

Middle Russian, a land document dated from the sixteenth century [Антонов, БАРАНОВ 1997, № 36];

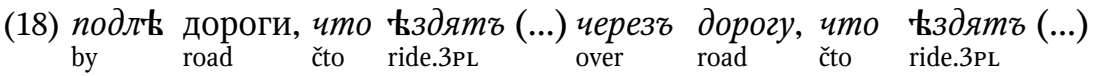

'by the road where one rides; across the road where one rides'

Middle Russian, a document signed by tsars Ioann Alekseevič

and Petr Alekseevič and tsarevna Sofja Alekseevna, 1682-1689

[BAXPOMEEB 1881].

The Old Russian example (19) exhibits the relativization of the verbal argument, though not the main one (the recoverability may be supported by the use of the same argument in the main clause):

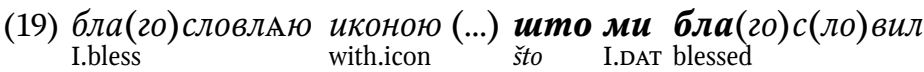

I.bless

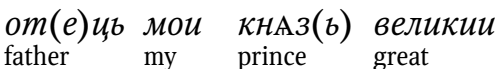

Old Russian, the testament of the grand duke of Moscow Vasilij

Dmitrievič, dated 1406 [Черепнин 1950, №20] (the same

construction is repeated in other versions of the testament, dated

from 1417 and 1423 [ЧЕРЕПнин 1950, №№21, 22]).

The construction is occasionally attested in Russian prose [ГРЯ 1980 2: 524], Russian dialects [ШАПиРо 1953: 112], in Ukrainian and Polish [MARETIĆ 1888: 11-12], and BCS, see [MARETIĆ 1888: 2; KoRDIĆ 1995: 162; VAN DER AUWERA, KUČANDA 1985: 942]. Some additional examples of similar usage of čto in the history of Russian are provided in [Троицкий 1959: 169] and [Борковский 1981: 215].

4.2. The interpretations. To sum up the preceding subsection, the "bare čto" strategy is most heavily used when the target is supposed to be in nominative, less consistently with accusative for the target, and only marginally otherwise. As the nominative and accusative may be roughly equated with subject and object respectively, this observation fits directly into accessibility hierarchy, a theory presented in a series of articles by E. Keenan and B. Comrie, see 
[KeENAN 1985: 147]. The relevant part of the hierarchy (we skip the distinctions between "other roles") looks like this:

subject $>$ direct object $>$ other roles

The higher the position in the hierarchy, the easier it is to relativize the position: thus, many relative strategies are limited to subject only or to subjects and direct objects only. The positions high in the hierarchy frequently make use of some strategy with no explicit marking of the relativization target. The lower the position, the more widespread is the use of the third-person pronoun for the target (note that the resumptive pronouns may co-occur with relative pronouns, as in non-standard English This is the road which I don't know where it leads [COMrIE 1989:140], see also [VAN DER AUWERA 1985: 156]). The special constructions for relativizing subjects are quite widespread in the form of "participles". The construction with no pronouns in relativizing subject and direct object targets is found, for instance, in English, Irish, and Welsh [KuRzové 1981: 84-85]. Slavic facts fit well into the accessibility hierarchy, as was implicitly noted in [KEENAN, COMRIE 1979a: 334] and explicitly in [KoRDIć 1995: 159-160].

Accessibility hierarchy can only account for differentiation of grammatical roles. How can we explain the difference between animate and inanimate direct objects? The most obvious interpretation is based on the fact that, in some important morphological patterns, Slavic animate accusative is distinct from inanimate accusative (the latter being the same as nominative) [KuRZOVÁ 1981: 80], [VAN DER AUWERA, KUČANDA 1985: 935]. ${ }^{3}$ It is worth stressing that this distinction is important not only for Slavic inflectional morphology, but for Slavic morphosyntax as well. The other possibility is put forward in [FRIED 2010]: she notes that in her sample of $c o$-relatives from colloquial Czech, $84 \%$ of accusative targets are inanimate, and she links this fact to "the universally observed tendency toward direct objects (patients) as entities that can be acted upon, manipulated, affected, etc. and, hence, prototypically inanimate things" [FRIED 2010: 21], making reference to the well-known article [HopPER,THOMPSON 1980]. The idea that animate direct objects are more "marked" than inanimate ones is discussed in typological perspective in [COMRIE 1989: 129-134] and [CROFT 2003: 166-167], though this approach received considerable skepticism in [Næss 2003].

Thus, the hierarchy of using two čto strategies may have a single interpretation: bare čto is used in the least marked context and an anaphoric pronoun is

3 Moreover, [Keenan, Comrie 1979b: 334] point out that the third pronoun marking is used in colloquial Czech "except for subject position and non-masculine or inanimate DOs". The masculine nouns mostly belong to the morphological pattern which discriminates between animate and inanimate nouns most consistently. But it is not clear in which source the cited difference between masculine and non-masculine is attested. 
added in the contexts which are more difficult to process (references to psycholinguistic data on subject and object relative clauses can be found in [HAWKINS 2004: 180-181], [GivóN 2009: 286] and [DuffielD, MiCHAELIS 2011]).

The examples (14-19) show that the "bare" strategy may also be used mostly not in standard language - in a broader set of contexts.

5. Pronoun or conjunction? So far, we have examined two constructions with Slavic čto, intentionally ignoring the syntactic category of the lexeme. The two main options are: conjunction ("complementizer") or relative pronoun. The decision, of course, may differ depending on the language in question. More specifically, the two constructions we have examined seem to differ. The standard bare čto (restricted to nominative and animate accusative) may be readily viewed as a pronoun with a defective paradigm. Discussing modern Russian (which exhibits only the bare čto construction), the paper [ЗАлизняк, ПАДУчевА 1975/2002: 669] explicitly argues for the pronoun option: «это может создать ложное восприятие такого что как несклоняемого слова (или даже как союза), тогда как в действительности оно просто не употребляется в падежах, где внешнее выражение не такое, как в исходной форме» (it may cause the misconception that чmo is an indeclinable word, even a conjunction, but in fact umo is just not used in cases with forms other than the basic one). The morphological interpretation of the animacy cut-off point in accusative, explicitly proposed by H. Kurzová, makes sense only within the pronoun version, and therefore supports it. The pronoun čto in the exact initial form really is the appropriate case form for subject and object, but still it is an invariable form.

The cases in which form of $\check{c} t o$ is not the appropriate case form for the relative target (both with "čto + pronoun" strategy and bare strategy as exemplified in (14-19) are not easily explainable within the pronoun approach, favouring instead the conjunction interpretation.

In [VAN DER AUWERA, KUČANDA 1985] the two interpretations (atypical relative pronoun and atypical relative conjunction) are tested against SerboCroatian što with the following conclusion: "Our account is irenic in that we hold both accounts to be correct, but only jointly so. Our account is no less ironic, however: we claim that when the analyses are meant to exclude each other, they are both wrong" [VAN DER AuwERA, KuČANDA 1985: 954]. Within any formal approach to grammar, the "two analyses" do not make any sense: at least as a technical solution, one category should be selected, and for those who consider parts of speech as a meaningful solution, the controversy may merit attention. But the universal categories are not necessary components of grammar. For example, within the framework of construction grammar, universal categories such as pronouns and conjunctions are an epiphenomenon of generalization over different constructions [CROFT 2000]. From this 
perspective the controversy around the categorization of čto simply does not exist. Diachronic changes along the grammaticalization paths regularly result in atypical grammatical units.

6. The inflected pronoun čto and the diachronic development of the invariable čto. The most obvious diachronic source of invariable čto is the inflected pronoun $\check{c} t o$, as conjunctions are regularly formed from pronouns ([LEHMANN 1984: 389-393] discusses such development in Latin in detail).

Slavic languages do possess the inflected pronoun čto. In Russian, the relative pronoun čto is limited to three kinds of relative constructions: those without a full noun (Данные статистики не совсем совпадают с тем, с чем сталкиваются аналитики 'Statistical data does not coincide with what analysts encounter'); without any overt head (Я нашел что искал 'I found what I was looking for'); and with a clause as an antecedent (Иномарка сбила лося, после чего вылетела на встречную полосу 'A foreign-made car knocked down an elk, after which it [the car] flew out into oncoming traffic'). The same is observed, for instance, in Croatian and related languages, [KoRDIć 1995: 144-149], [GALLIS 1956: 56]. The inflected pronoun čto is the counterpart of the relative $k t o$ and is used almost exclusively for inanimates. The invariable (uninflected) čto, the subject of the present investigation, is used mainly with nouns, either inanimate or animate, as well as with animate NPs without a noun (те, что пришли 'those who came'). Some mediaeval Slavic texts show rare instances of the inflected čto with full nouns, that is, some oblique case forms. Instrumental case $u \mathbf{k} \mathcal{M} z$ shows up in the Old Russian cliché $o(m) u(u) \mathcal{H} z \boldsymbol{u} \mathbf{k} \mathcal{M} z$ есмг его бл(а)г(о)с(ло)вилг lit. "legacy with which I blessed him" (a testament dated 1389, [ЧЕРеПнин 1950, №12], the same in [ЧЕРеПнин 1950, №32], cf. [БоркОвский 1958: 125] on such examples); different forms are attested in Old Serbian documents, [PAVlović 2009: 128]; see further references in [VAN DER AUWERA, KUČANDA 1985: 935]. The official Russian grammar [ГРЯ 1980 2: 525] provides an example with an inanimate head noun (облачается в свитку, чем укрывался ночью '[Hе] puts a svitka (a sort of overclothes) on, with which [he] covered himself at night') without commenting on its grammaticity; actually such examples (paired with $\kappa m o$-relatives with head noun, also exemplified in [ГРЯ 1980]), are taken from nineteenth-century literature and are highly unusual for modern Russian and should better be deemed almost non-existent. The oblique forms of the inflected pronoun čto seem to be limited to inanimate full nouns, as is explicitly stated for Polish in [NIEMINEN 1950: 100] and is confirmed by examples in [ПАвловић 2009: 128]; moreover, [GEBAUER IV: 249] states that relative Old Czech co is restricted to inanimates, and [GALLIS 1956: 54-55] enumerates nouns (mostly commercial and legal terms) which typically occur with čto; see also references in [VAN DER AUWERA, KuČANDA 1985: 935]. 
A regular relative pronoun occurs in any syntactic role using the appropriate case. Syntactic roles differ crucially in their relative frequency in the texts; thus, subject NPs outnumber all others. It would come as no surprise if relative pronouns appeared in subject position with even higher frequency, as pronoun-headed or definite noun phrases tend to be subjects [COMRIE 1989: 128, CROFT 2003: 179-180 passim]. The reduction of the paradigm may have happened as a gradual fading, almost unnoticed: some rare forms occurred more and more rarely (one should also bear in mind that the čbto type of relative clause is not the main one). A similar morphosyntactic reduction is attested with the relative pronoun койmo in Bulgar "damascenes" of the seventeenth century. Only the form койmo (historically Nom. Sg. masc.) was used. As [ДЕмина 1975: 128] states, the use was mostly restricted to masculine human antecedents (and feminine singular antecedents were not allowed). At that time, colloquial spoken Bulgarian already lacked relative pronouns, using relative conjunctions instead. This development contrasts with the more usual one, in which one of the forms takes over the functions of the other form: for example, the Middle Bulgarian relative pronoun «жe (historically Nom. Sg. neutr.) stood for all gender and number forms, see [VONDRÁK 1908: 456-457; Минчева 1982: 197]. In Old Serbian and Old Croatian both єже and иже (historically Nom. Sg. masc.) were used as a common form for all genders and numbers [GALLIS 1956: 21, 30, 76].

The diachronic formation of the invariable čto is not as clear and straightforward as simply the loss of the paradigm (or, to put it another way, decategorization). The new "relativum absolutum" coincides with the main complementizer (as in Russian Он сказал, что... 'He said that...') - the syncretism also attested in Iranian and Semitic languages, see [ЗАлизняк, ПАдучевА 1975/2002: 685-687]; the case of English that is discussed in great detail in [VAN DER AUWERA 1985]. The historical controversy here lies in the fact that the Slavic complementizer čto is believed to stem from the relative pronoun (see [HEINE, KutEva 2004: 254] for typological analogies), so we may either simply posit the parallel emergence of two conjunctions from the relative pronoun or insist that the complementizer somehow influenced the rise of the relative conjunction. The other cases of Slavic complementizers used as relative conjunctions are Old Czech and Lower Sorbian jako [MARETIĆ 1888: 3-4], and Czech, Polish, and Ukrainian *že [MARETIĆ 1888: 2-3] (T. Maretić supposed, though, that this * že stems from Slavic *ježe). The fact is that West Slavic languages have relative $c o$ (Slovak $\check{c}$ ), but almost completely lack the complementizer (see, however, [КУРАшКЕВИч 1971]).

The least pronominal usage of $\check{c} t o$ is the East Slavic construction combining čto with the main relative pronoun которыи (которыи is the Old Russian form corresponding to Modern Russian который), as exemplified in (20): 
(20) $m \mathbf{k}$ мъ волостем, что ми ес (u) которые придал к Вышегороду

Old Russian, 1450 [ЧЕРеПнин 1950, №55]

Some examples of this pattern are provided in [Троицкий 1959: 169] and [КАРский 1955: 472]. Such usage may be better attributed directly to the main complementizer čto.

The pair of constructions (with and without the resumptive pronoun, depending on case) may not stem from Common Slavic. Old Church Slavonic lacks the relative umo altogether, but this may be due to some stylistic reasons. ${ }^{4}$ The crucial point is that similar pairs of constructions are not restricted to the single lexeme under discussion. According to [LENCEK 1982: 225], in Slovene "the indeclinable $k i$ is used in all but the masculine singular form in combination with a personal pronoun”. Václav Vondrák [VoNDRÁK 1908: 453] cites examples of the construction "kenž + pronoun" in Lower Sorbian; Arne Gallis [GALLIS 1956: 30] cites examples of ıжe followed by third-person pronoun in Old Serbian. A similar distribution of the two constructions is also attested in Romance languages, as well as in German and Greek, thus exhibiting an areal trait [KuRzová 1981: 80-84]. Moreover, Romance languages (especially in their non-standard forms) also exhibit the same ambiguity, as one and the same lexeme serve both as relativizer and complementizer (Italian che, Spanish and Catalan que [RAMAT 2005: 117]).

7. Conclusion. The discussion may be summarized as follows. One formal question, inevitably faced in connection with čto, is its syntactic category, as its behaviour is atypical for both pronouns and conjunctions. The present paper does not argue for either option, but presents the data on (at least) two distinct constructions with a single lexeme: in one of them ("bare čto", examples (1) and (13)), the lexeme is more pronoun-like, while in the other (čto + anaphoric pronoun, examples (2-12) and (14-20)), there are some distinct conjunction-like traits. [Акимова 1964: 142] questions whether these two are simply two versions of a single construction. She points to the difference in frequency, but an even more significant reason to treat them as separate is the semantic difference, indicated in [FRIED 2010]: clauses with a third-person pronoun are likely to have a parenthetical reading, and they are attached to the head noun less tightly. The correlation between the use of a resumptive pronoun and a non-restrictive (parenthetical) reading is observed in Modern Greek [AlExopolou 2006: 70]; the correlation between

4 Interestingly, Vuk Karađić believed the absence of the relativizer in Old Church Slavonic was artificial: „Relative pronoun što is in use in all modern Slavic nations, but Old Church Slavonic lacks it. No doubt ancient Slavs used the pronoun; it is only that translators left it out as they thought it to be a defective usage of herdsmen and swineherds, as it is not found in Greek and Latin” [КАРАџИЋ 1894-1895: 62-63], cited in [DMITRIEV 1972: 287-288]. 
the resumptive pronoun and greater linear distance (and, hence, lesser accessibility) is observed in [ARIEL 1994: 29].

The most frequent construction with čto, which we called "bare čto", is compatible with both analyses of $\check{c} t o$ - both as a form of a pronoun and as a conjunction. It is in this context that the inflected pronoun was most likely reanalysed as an invariable relativizer (according to classification in [CROFT 2000], this is an instantiation of hypoanalysis, a process whereby a contextual property is reanalyzed as an inherent property of the syntactic unit [CROFT 2000: 126]). The actualization of the reanalysis can be seen in the formation of the second construction, čto + anaphoric pronoun, which was introduced for less frequent contexts. The complementizer $\check{c} t o$, which stems from the same inflected pronoun, may also have influenced the formation of the invariable relativizer. But as the pair of constructions is not restricted to Slavic čto, a replication of the areal pattern is also possible.

The most interesting point for synchronic investigation is probably not the relativizer's part of speech (though it poses evident problems), but the exact cut-off point between the two competing constructions. The competition was examined in detail in [FRIED 2010] for modern Czech, pointing to an interesting interplay of different factors. The details may vary in Slavic languages, but the tendencies are most likely the same. We believe that the joint analysis of these constructions in Slavic languages may immensely enrich the understanding of individual languages.

\section{References}

Alexopolou 2006

AleXopolou T., "Resumption in relative clauses", Natural language and linguistic theory, 24/1, $57-111$.

ANDREWS 2007

ANDrews A.D., "Relative Clauses", in: T. SHOPEN (ed.), Language Typology and Syntactic Description $^{2}$ (= Complex Constructions, 2), Cambridge.

ARIEL 1994

ARIEL M., "Interpreting Anaphoric Expressions: A Cognitive versus a Pragmatic Approach", Journal of Linguistics, 30, 3-42.

BARTOŠ 1905

BARToš F., Dialektický slovník moravský, I, Praha.

CitKo 2004

Сiтко B., "On Headed, Headless, and Light-Headed Relatives", Natural Language and Linguistic Theory, 22/1, 95-126. 


\section{COMRIE 1989}

Comrie B., Language Universals and Syntactic Description. Syntax and Morphology ${ }^{2}$, Chicago.

\section{Cristofaro, RAMAT 2007}

Cristofaro S., RAMAT A.G., "Relativization Strategies in the Languages of Europe", in:

P. RAmAт, E. Roma (eds.), Europe and the Mediterranean as Linguistic Areas: Convergencies from a Historical and Typological Perspective, Amsterdam, Philadelphia, 63-93.

CROFT 2000

Croft W., Explaining Language Change, Harlow, New York.

Croft 2003

CROFT W., Typology and Universals ${ }^{2}$, Cambridge.

Duffield, Michaelis 2011

Duffield C.J., Michaelis L.A., "Why Subject Relatives Prevail: Constraints versus Constructional Licensing”, Language and Cognition, 3, 171-208.

GALLIS 1956

Gallis A., The Syntax of Relative Clauses in Serbo-Croatian: Viewed on a Historical Basis, Oslo.

\section{GEBAUER IV}

Gebauer J., Historická mluvnice jazyka českého, IV (Skladba), Praha, 1929.

GIVÓN 2001

Givón T., Syntax: An Introduction, rev. ed., II, Amsterdam, Philadelphia.

GIVón 2009

Givón T., The Genesis of Syntactic Complexity. Diachrony, Ontogeny, Neuro-cognition, Evolution, Amsterdam, Philadelphia.

GOLĄB, FRIEDMAN 1972

Goląb Z., Friedman V. A., “The Relative Clause in Slavic”, in: P. M. Peranteau, J. N. Levi, G.C. Phares (eds.), The Chicago Which Hunt, Papers from the Relative Clause Festival, Chicago, 30-46.

GROCHOWSKI et al. 1984

GrochowsKi V., KAROLAK S., Topolińska Z., Składnia (= Gramatyka współczesnego języka polskiego, 1), Warszawa.

FRIED 2010

FrIED M., "Accusative Resumptive Pronoun in the Czech Relative Clauses with Absolutive Relativizer co", Korpus, gramatika, axiologie, 1/1, 16-29.

HAIMAN 1985

Haiman J., Natural Syntax, Cambridge.

НАММ 1974

HAMM J., Staroslavenska gramatika, Zagreb.

HARRIS, CAMPBELL 1995

Campbell L., Harris A. C., Historical Syntax in Cross-Linguistic Perspective, Cambridge.

HASPELMATH 2001

Haspelmath M., "The European Linguistic Area: Standard Average European”, in:

M. HASPelmath, E. KÖNIG, W. OesterReicher, W. Raible (eds.), Language Typology and Language Universals: An International Handbook, 2. New York.

HAWKINS 2004

HAW KINS J., Efficiency and Complexity in Grammars, Oxford.

Heine, Kuteva 2004

Heine B., Kuteva T., World Lexicon of Grammaticalization, Cambridge. 
Heine, Kuteva 2005

Heine B., Kuteva T., Language Contact and Grammatical Change, Cambridge.

Heine, Kuteva 2006

Heine B., Kuteva T., The Changing Languages of Europe, New York.

HOPPER, THOMPSON 1980

Hopper P., THOMPSON S., “Transitivity in grammar and discourse”, Language, 56, 251-295.

KEENAN 1985

KeEnAn E., "Relative Clauses", in: T. SHopen (ed.), Language Typology and Syntactic

Description, 2. Cambridge, 141-170.

KEENAN, COMRIE 1977

KeEnAN E. L., Comrie B., "Noun Phrase Accessibility and Universal Grammar”, Linguistic

Inquiry, 8, 63-99.

KeENAN, CoMrie 1979A

Keenan E. L., Comrie B., "Data on Noun Phrase Accessibility Hierarchy”, Language, 55/2, 333-351.

KeENAN, COMRIE 1979b

Keenan E.L., Comrie B., “Noun Phrase Accessability Revisted”, Language, 55/3, 649-664.

KORDIĆ 1995

KoRDIĆ S., Relativna rečenica, Zagreb.

KotT I.

Котт F. Š., Česko-německý slovník zvláště grammaticko-fraseologický, I, Praha, 1878.

KŘIŽKOVÁ 1970

KŘıžKovÁ H., “Relativní věty v současných slovanských jazycích”, Slavia, 39, 10-40.

KurzovÁ 1981

KuRzovÁ H., Der Relativsatz in den indoeuropäischen Sprachen, Hamburg.

LEHMANN 1984

Lehmann C., Der Relativsatz, Tübingen.

LENCEK 1982

LENCEK R., The Structure and History of the Slovene Language, Columbus (Ohio).

LUNT 1952

LunT H., Grammar of the Macedonian Literary Language, Skopje.

MARETIĆ 1888

MARETIĆ T., "Veznici v slovenskijem jezicama”, Rad jugoslavenske akasemije znatnosti i umjetnost, XCI, $1-80$.

NAESS 2003

NAESS Å., "What Markedness Marks: The Markedness Problem with Direct Objects”, Lingua, $114 / 9-10,1186-1212$.

NIEMINEN 1950

NIEMINEN E., Beitrage zur altpolnischen Syntax, Helsinki.

ONDRUS 1956

ONDRUS P., Stredoslovenské nárečia v mad'arskej l'udovej republike, Bratislava.

PUGH 2006

Pugh S. M., "Relative Constructions in Contemporary Popular Russian Prose. Reflections on Changing Language”, Russian Linguistics, 30/2, 213-266. 
RAMAT 2005

Ramat A.G., "Persistence and Renewal in the Relative Pronoun Paradigm: The Case of Italian", Folia Linguistica Historica, 26/1-2, 115-138.

VAN DER AUWERA 1985

VAN DER AuWERA J., "Relative that - a Centennial Dispute”, Journal of Linguistics, 21, 149-179.

VAN DER AuWERA, KuČANDA 1985

VAN DER AuWERA J., KuČANDA D., "Serbo-Croatian što - Pronoun or Conjunction?”, Linguistics, 23, 917-962.

VONDRÁK 1908

VONDRÁK W., Vergleichende Slavische Grammatik, 2: Formenlehre und Syntax, Göttingen.

\section{АКИМовА 1964}

АкимовА Г.Н., “Тенденции в развитии относительного подчинения в современных восточнославянских языках", Известия Академии Наук СССР, серия литературы и языка, XVIII, 2 (март - апрель), 138-144.

АНТОНОВ, БАРАНОВ 1997

Антонов А.В., БАРАнов К.В. (сост.), Акты служилых землевладельцев ХV- начала XVII века, Москва.

\section{АФАНАСЬЕВ}

Народные русские сказки А.Н. Афанасьева, I-III, Москва, 1958.

\section{Борковский 1958}

Борковский В.И., Синтаксис древнерусских грамот. Сложное предложение, Москва.

БорковСкий 1981

Борковский В.И., Синтаксис сказок. Русско-белорусские параллели, Москва.

БУСлАЕв 1959

БУслАЕв Ф.И., Историческая грамматика русского языка, Москва.

ВАХРОМЕЕВ 1881

ВАХромеЕв И.А. (изд.), Княжие и иарские грамоты Ярославской губернии, Москва.

ГРЯ 1954 II

В. В. ВИНОГРАдов, Е.С. ИстринА (ред.), Грамматика русского языка, ІІ, 1-2, Москва.

ГРЯ 1980

Н.Ю. ШведовА (гл. ред.), Русская грамматика, Т. 2: Синтаксис, Москва.

ГРИНЧЕНКО

ГРИнченко Б. Д., Словарь української мови, 1-4, Київ, 1907-1909.

ДЕМИНА 1975

ДЕмИнА Е.И., “Из болгарского исторического синтаксиса. Сложные предложения с союзным словом който в языке дамаскинов XVII в.”, в: Г.П. КлеПиковА (ред.), Славянское и балканское языкознание. Проблемы интерференци и языковых контактов, Москва.

ДМИТРИЕв 1972

ДмитриЕв П.А., “К вопросу о вариативности присубстантивно-относительных придаточных в сербохорватском языке”, в: Р.В. БулАтовА (ред.), Исследования по сербохорватскому языку, Москва, 276-323. 
ЗАЛИЗНЯК, ПАДУЧЕВА 1975/2002

ЗАЛИЗНЯК А.А., ПАдУчЕВА Е.В. “К тиПологии относительного предложения”, в:

О.М. МихАйлов (ред.), Семиотика и информатика, 1974, 6, Москва, 51-101; цитируется по переизданию: А. А. ЗАлизняк, Русское именное словоизменение, Москва, 648-698.

КАРАџИ 1894-1895

КАРАЏИЋ В., СКУплеНИ граматичкИ и полемички списи, ІІ, Београд.

КАРСКИЙ 1955

КАРСКИЙ Е. Ф., Белорусы. Язык белорусского народа, 2-3, Москва.

КУРАШКЕВИЧ 1971

КУРАШКЕВИЧ В., “ПоЛЬСКОе местоИмение со в фУНКциИ соЮЗа żе”, В: Р.И. АВАНЕСов и дР. (ред.), Проблемы истории и диалектологии славянских языков. Сборник статей к 70-летию члена-корреспондента АН СССР В. И. Борковского, Москва, 164-170.

МИНЧЕвА 1982

МинчевА А., “К синтаксической характеристике среднеболгарских евангельских списков (Рыльское Б Евангелие)”, в: Е.И. ДЕминА И дР. (ред.), Язык и письменность среднеболгарского периода, Москва, 194-225.

ПАвловић 2009

ПАвловић С., Старосрпска зависна реченица од ХII до XV века, Нови Сад.

РОМАНОВ 1901

Романов Е.Р., Белорусский сборник, 6, Сказки, Могилев.

Троицкий 1959

ТРОИцКИй В.И., “К истории союза что в русском языКе”, в: В.В. ВиногРАдов (ред.),

Славянское языкознание, Москва, 160-169.

ЧЕРЕПНИН 1950

ЧЕРеПнИн Л. В. (подгот. к печати), Духовные и договорные грамоты великих и удельных князей XIV-XVI вв., Москва, Ленинград.

ШАПИРО 1953

ШАПиРо А.Б., Очерки по синтаксису русских народных говоров. Строение предложения, Москва.

Фидипп Робертович Миндос, к.ф.н.

Институт славяноведения РАН

119334 Москва, Ленинский проспект, 32-А

f.minlos@gmail.com 